\title{
PENGARUH PEMBELAJARAN PROBLEM SOLVING BERBANTUAN PhET TERHADAP PENGUASAAN KONSEP SISWA PADA MATERI MOLARITAS
}

\author{
Indrawati \\ SMA Negeri 10 Kota Jambi \\ selvirahmawati04@gmail.com
}

\begin{abstract}
Abstrak
Penelitian ini merupakan penelitian eksperimen kuasi dengan posttest only design. Pengambilan data dilakukan dengan tes penguasaan konsep sebanyak 20 soal setelah diberikan perlakuan pada 3 kelompok kelas. Kelompok pertama adalah siswa yang belajar dengan pembelajaran problem solving berbantuan PhET, kelompok kedua adalah siswa yang belajar dengan pembelajaran problem solving, dan kelompok ketiga adalah siswa yang belajar dengan pembelajaran konvensional. Sebelum diberikan perlakuan dan pengambilan data, instrumen penelitian yang digunakan telah melalui uji ahli dan uji coba. Teknik analisis data menggunakan uji Manova satu jalur dilanjutkan dengan uji Tukey. Hasil penelitian menunjukkan bahwa terdapat perbedaan signifikan penguasaan konsep antara siswa yang belajar dengan pembelajaran problem solving berbantuan PhET, pembelajaran problem solving, dan pembelajaran konvensional. Perbedaan ini disebabkan adanya proses pembelajaran yang berbeda antara ketiga kelompok kelas. Penguasaan konsep siswa yang menggunakan pembelajaran problem solving berbantuan PhET lebih tinggi dari siswa yang menggunakan pembelajaran problem solving dan pembelajaran konvensional
\end{abstract}

Kata Kunci: Problem Solving, PhET, Molaritas, Penguasaan Konsep

\begin{abstract}
This research is a quasi experimental research with posttest only design. Data retrieval is done with a concept mastery test of 20 questions after being treated in 3 groups of classes. The first group is students who study with PhET-assisted problem solving learning, the second group is students who learn by problem solving learning, and the third group is students who study with conventional learning. Before being given treatment and data retrieval, the research instrument used has been through expert testing and trials. The data analysis technique used the Manova one-way test followed by the Tukey test. The results showed that there were significant differences in the mastery of concepts between students learning with PhETassisted problem solving learning, problem solving learning, and conventional learning. This difference is due to the different learning processes between the three class groups. Mastery of the concept of students who use PhET-assisted problem solving learning is higher than students who use conventional problem solving learning and learning
\end{abstract}

Keywords: Problem Solving, PhET, Molarity, Concept Mastery

\section{PENDAHULUAN}

Proses pembelajaran lebih menitikberatkan peran aktif peserta didik dalam kegiatan belajar, seorang pendidik hanya sebagai fasilitator dan motivator (Sujarwata, 2009). Siswa diharapkan dapat memahami materi dengan menghubungkan pembelajaran dengan konteks kehidupan sehari-hari sehingga membuat kegiatan pembelajaran di kelas semakin bermakna. Proses pembelajaran dapat dikatakan bermakna apabila dilakukan dengan metode ilmiah (Wilhelm dkk, 2007). Pembelajaran akan lebih bermakna jika pembelajaran bersifat inovatif. Pada bidang pendidikan, inovatif diartikan sebagai suatu perubahan yang bersifat baru dan kualitatif, yang berbeda dengan hal sebelumnya dan bertujuan untuk meningkatkan sumberdaya manusia guna mencapai tujuan tertentu dalam pendidikan (Sujarwata, 2009).

Penggunaan media pembelajaran dalam proses belajar mengajar dapat membangkitkan keinginan dan minat baru serta membangkitkan motivasi dan rangsangan untuk belajar (Arsyad, 2011). Salah satu cara untuk memunculkan minat dan motivasi belajar siswa dengan bantuan 
game atau permainan. Menurut Munadi (2012), "Permainan adalah media yang digunakan untuk memperoleh kesenangan sekaligus pengetahuan”. Selain itu menurut Randel (Fadly, 2012) menyatakan bahwa, "Game sangat berpotensi untuk menumbuhkan kembali motivasi belajar anak yang mengalami penurunan". Berdasarkan penelitian yang dilakukan oleh Randel pada tahun 1991 tercatat bahwa pemakaian game sangat bermanfaat pada materi-materi yang berhubungan dengan matematika, sains dan kemampuan berbahasa (Fadly, 2012).

Game yang paling diminati oleh pelajar saat ini adalah game komputer. Anonim (2012) menyatakan bahwa Game komputer adalah sebuah program software dimana satu atau lebih pemain berusaha untuk membuat keputusan lewat kontrol terhadap object dan resource guna memenuhi satu tujuan tertentu.

Terdapat beberapa macam game berdasarkan genre antara lain Game PhET interactive Simulation. Simulasi PhET merupakan simulasi yang dibuat oleh Universitas Colorado yang berisi simulasi pembelajaran sains untuk kepentingan pengajaran di kelas atau belajar individu (Prihatiningtyas, 2013). Kelebihan dari simulasi PhET yakni simulasi ini bersifat interaktif dan menarik dikemas dalam bentuk seperti permainan. Simulasi PhET menekankan hubungan antara fenomena kehidupan nyata dengan ilmu yang mendasari, mendukung pendekatan interaktif dan konstruktivis, memberikan umpan balik, dan menyediakan tempat kerja kreatif (Finkelstein, 2006).

Berdasarkan uraian di atas, maka penulis tertarik untuk melakukan penelitian tentang pengaruh pembelajaran problem solving berbantuan phet terhadap penguasaan konsep siswa pada materi molaritas.

\section{METODE}

Penelitian yang dilakukan merupakan penelitian eksperimen kuasi (quasi experiment) dengan menggunakan tiga kelas yaitu dua kelas eksperimen dan satu kelas kontrol. Kelas eksperimen yang pertama diberikan perlakuan berupa strategi pembelajaran problem solving berbantuan media simulasi PhET, kelas eksperimen kedua diberikan perlakuan berupa strategi pembelajaran problem solving, sedangkan kelas kontrol diberikan perlakuan strategi pembelajaran konvensional.

Desain penelitian ini menggunakan posttest only design dengan skema seperti dalam Tabel 1.

Tabel 1. Skema Rancangan Penelitian Kelas

\begin{tabular}{|l|l|l|l|}
\hline \multirow{2}{*}{ Kelas } & \multirow{2}{*}{ Perlakuan $(\mathbf{X})$} & \multicolumn{3}{|l|}{ Setelah Perlakuan } \\
\cline { 3 - 4 } & & $\mathbf{Y}_{\mathbf{1}}$ & $\mathbf{Y}_{\mathbf{2}}$ \\
\hline $\mathrm{A}_{1}$ & $\mathrm{X}_{1}$ & $\mathrm{O}_{1}$ & $\mathrm{O}_{4}$ \\
\hline $\mathrm{A}_{2}$ & $\mathrm{X}_{2}$ & $\mathrm{O}_{2}$ & $\mathrm{O}_{5}$ \\
\hline $\mathrm{A}_{3}$ & $\mathrm{X}_{3}$ & $\mathrm{O}_{3}$ & $\mathrm{O}_{6}$ \\
\hline
\end{tabular}

(Sumber: diadaptasi dari Creswell, 2012)

Dalam penelitian ini yang menjadi populasi adalah kelas X SMA Negeri 10 Kota Jambi. Teknik pengambilan sampel diambil menggunakan metode kelas random sampling, yaitu dengan mengundi semua kelas yang ada. Pengambilan sampel dilakukan secara acak dengan menuliskan kelas di kertas kecil dan memilihnya tanpa mengetahui tulisan di dalamnya. Dengan demikian diperoleh sampel yang terdiri dari 2 kelas eksperimen dan 1 kelas kontrol.

Data yang dibutuhkan dalam penelitian ini adalah data tentang tes penguasaan konsep Molaritas. Teknik analisis data menggunakan uji Manova satu jalur dilanjutkan dengan uji Tukey.

\section{HASIL DAN PEMBAHASAN}

Penguasaan konsep siswa diukur dengan menggunakan instrumen penguasaan konsep berupa tes pada pokok bahasan Molaritas. Instrumen tes yang digunakan dibuat berdasarkan pada indikator pencapaian konsep berdasarkan taksonomi Bloom yang direvisi. Instrumen ini terdiri atas 20 soal pilihan ganda. Tes tersebut dilaksanakan setelah proses pembelajaran pada pokok bahasan molaritas.

Hasil penelitian menunjukkan adanya selisih nilai rata-rata penguasaan konsep molaritas siswa antara kelas eksperimen dan kelas kontrol. Pada kelas dengan pembelajaran problem solving berbantuan PhET memiliki nilai rata-rata 76,7 . Pada kelas dengan pembelajaran problem solving 
memiliki nilai rata-rata 71,3 . Sedangkan pada kelas yang belajar secara konvensional memiliki nilai rata-rata 65 . Jika ditampilkan dalam bentuk diagram akan tampak seperti Gambar 1.

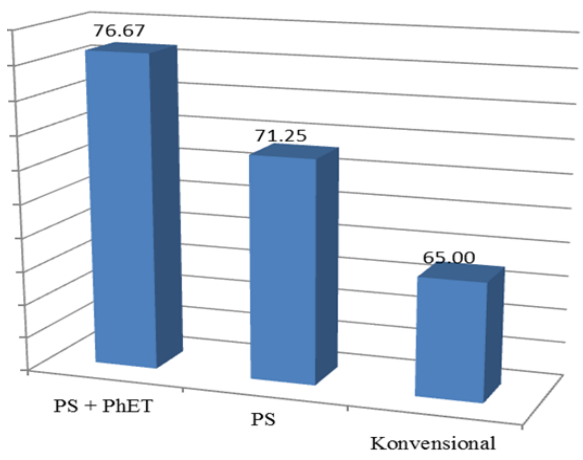

Gambar 1. Diagram penguasaan konsep siswa

Hasil analisis ini menunjukkan bahwa penguasaan konsep siswa yang belajar dengan pembelajaran Problem solving berbantuan PhET lebih efektif daripada siswa yang belajar dengan pembelajaran Problem solving saja dan pembelajaran konvensional. Hasil ini sesuai dengan penelitian Selcuk (2008) yang menunjukkan adanya perbaikan penguasaan konsep setelah siswa belajar menggunakan Problem solving. Selain itu, Media simulasi PhET merupakan salah satu media simulasi virtual yang dapat meningkatkan penguasaan materi siswa (Flowers, 2011).

Penguasaan konsep siswa yang belajar dengan pembelajaran Problem solving

\section{DAFTAR PUSTAKA}

Arsyad, Azhar. 2009. Media Pembelajaran. Jakarta: PT Raja Grafindo Persada.

Anonim. 2012. Diakses 26 Februari 2013. Pengertian kuis. http://serbakuis.blogspot.com/2013/02/ pengertian-kuis.html.

Creswell, J.W. 2012. Educational Research. Boston: Pearson.

Finkelstein, N. 2006. High-Tech Tools for Teaching Physics: The Physics Education Technology Project. Merlot Journal of Online Learning and Teaching, (Online), 2(3): 110-121, (www.jolt.merlot.org) diakses 12 Juni berbantuan PhET lebih efektif juga dikarenakan Simulasi dalam PhET bersifat interaktif dikemas dalam bentuk seperti game/permainan sehingga siswa merasa termotivasi dan tertantang untuk membuktikan hasil praktikum secara langsung melalui $\mathrm{PhET}$ tersebut. Hasil temuan ini sesuai dengan hasil penelitian Tuysuz (2010) yang menyatakan bahwa fenomena dan konsep-konsepnya yang terkait dengan simulasi serta terkait dengan aplikasi keseharian siswa dapat menambah pengetahuan siswa secara visual dan menstimulus lebih banyak siswa untuk mencapai tingkat penguasaan yang tinggi mengenai konsep.

\section{SIMPULAN}

Berdasarkan hasil penelitian dan pembahasan yang diuraikan, dapat ditarik kesimpulan bahwa terdapat perbedaan penguasaan konsep yang signifikan antara siswa yang belajar dengan pembelajaran problem solving berbantuan PhET, pembelajaran problem solving, dan pembelajaran konvensional. Siswa yang belajar dengan problem solving berbantuan PhET memiliki penguasaan konsep kimia lebih baik daripada siswa yang belajar dengan pembelajaran problem solving dan pembelajaran konvensional..

2013.

Fadly, Arief. 2012. Diakses 17 Februari 2013. Pengertian Game mobile learning untuk pendidikan. http://www.google.com/gwt/x?hl=id\& $\mathrm{u}=\mathrm{http}: / / \mathrm{www}$. techforedu.org/2012/08/ pengertian-game-mobilelearninguntuk.html\&client $=\mathrm{ms}+\mathrm{samsu}$ ng\&q=pengertian+game\&sa $=X \& e i=v q$ AgUYailMLprAzwICADg\&ved $=o C D$ oQFJAI.

Munadi, Yudhi. 2012. Media Pembelajaran Sebuah Pendekatan Baru. Jakarta: Gaung Persada Press. 
Prihatiningtyas, S., dkk. 2013. Implementasi Simulasi PhET dan Kit Sederhana untuk Mengajarkan Keterampilan Psikomotor Siswa pada Pokok Bahasan Alat Optik. Jurnal Pendidikan IPA Indonesia, (Online), 2(1): 18-22, (www.unnes.ac.id) diakses 12 Juni 2013.

Sujarwata. 2009. Peningkatan Hasil Belajar Elektronika Dasar II Melalui Penerapan Model Pembelajaran Problem Solving Laboratory. Jurnal Pendidikan Fisika Indonesia, (Online), 5(1): 37-41, (www.unnes.ac.id) diakses 21 April 2013.

Selcuk, G.S., Caliskan, S., dan Erol, M. 2008. The Effect Of Problem Solving Instruction On Physics Achievement,
Problem Solving Performance And Strategy Use. Latin-American Journal of Physics Education, (Online), 2(3): 151-166, (www.journal.lapen.org.mx), diakses 21 April 2013.

Tuysuz, C. 2010. The Effect of the Virtual Laboratory on Students Achievement and Attitude in Chemistry. International Online Journal of Educational Sciences, (Online), 2(1): 37-53, (www.iojes.net) diakses 12 Juni 2013.

Wilhelm, J., Thacker, B dan Wilhelm, R. 2007. Creating Constructivist Physics for Introductory University Classes. Electronic Journal of Science Education, 11(2): 19-37. 